general: what is required is more than an increased emphasis on ecology as a "subject" to which time is given in biological courses. If it is really to "be said with confidence that the 1970's will mark the first moment during man's tenure of this earth when the nature and conduct of his stewardship will be continuously under critical scientific scrutiny, not too far separated from the seats of power and from the enforcement of accountability", there must be a much more widespread appreciation of the nature of ecological problems and solutions than merely among the scientific advisers of the future masters of the Earth. Those masters must themselves learn to think ecosystematically, and this is a problem for the educational system as a whole.

It is of interest that Max Nicholson's tempored optimism about tho future role of ecological theory and practice stems to a considerable extent from his strong belief that systems analysis, model-making and the computer will revolutionizo ecological research and thinking. An important reason for the past failure of ecologists to earn and secure recognition as "real" scientists has bocn the difficulty of applying rigorous quantitative methods to systems as complex as natural ecosystems. The requisite tools are now available, and they should attract an ever growing number of workers of high calibre into that kind of ecological research, into natural, somi-natural and wholly artificial ocosystems, that must, as Max Nicholson so clearly sees, determine how far man is to be successful in harmonizing himself and his environment in tho difficult days to come.

A. R. CLAPHAM

\section{DARWIN TRIUMPHANT}

The Triumph of the Darwinian Method

By Michael $T$. Ghiselin. Pp. $x+287$. (University of California Press: Berkeley, Los Angeles and London, Novembor 1969.) $72 s ; \$ 7.50$.

THIs critical examination of Darwin's pullished works is a welcome addition to the existing works of this nature becauso Dr Ghiselin approaches his task from a training in zoology and logic. He has not made use of the extensive, still unpublished, manuscript material, but he has clearly read widely in the superabundant commentary triggered by the centenary of the publication of the Origin in 1959. A high proportion of this recent appraisal was exccedingly critical in tone. Darwin was an allegedly representative Victorian ripe for debunking on tho lines laid down by Lytton Strachey from which process there emerged accusations of plagiarism, unconscious if the critic felt kindly disposed, shifty compromise in the face of criticism, and occasional downright dishonesty. This book cxamines the published works and their critics to such effect that Darwin emerges transformed. Sound in logic and with a healthy metaphysic his total publishod work, even that on barnaclos, allegedly undertaken because he had not the moral courage to press on and publish his transmutation theories, and on plant physiology, regarded as the rolaxation of a tired cvolutionist, is now shown to have a hitherto unrecognized coherence and unity. Few of the critics emerge unscathed, though the full appreciation of the extent of their injuries rcquircs careful research on the part of the reader into the extensive footnotes and cspecially into their internal cross-referonces. The quality of grasp of sources requires a library of the correct editions of Darwin's books for a full appreciation. Few of the exceedingly pertinent passages aro quoted, so that the general reader will find it hard to do justice to the perceptive insights lavished by the author. The frequent tochnical terms and contorted phraseology often noedlessly hold up the concisely pointed argument. The book is aceordingly difficult to comprehend but, in spite of that, doserves a strong claim for the close reading required on the part of all concerned with biology.
Ghiselin's thesis derives from "a conceptual analysis of (Darwin's) theoretical constructs" and demonstrates that ho operated as a basis for his rcasoning from a "sclcctiveretention" model. In such a model, a restriction of randomness by external circumstances supplies a directional effect. Thinking is developmental and embryological and, although Darwin never openly and unequivocally acknowledged this, the enthralling analysis of the "Variation" in the seventh chapter reveals alike the triumphs and failures of the Darwinian method, notably in the provisional hypothesis of "Pangenesis", and as a conclusion acquits Darwin of the charge of "abandoning natural selection, and of becoming a Lamarckian". His refusal "to rationalizo appearances as owing to reason or design" in order to put "meaningful questions about the processes that might have generated the observed phenomena" is considered of crucial importance. In short, "evolution produces contraptions, not contrivances". Ghiselin's concluding remark about Professor Darlington's strictures doscrves quotation: "It seems hardly rational, in treating of Darwin's genetics along with the rest of his contributions, to condemn the Copernicus and Newton of biology for not being its Einstcin as woll".

Darwin had "a peculiar gift for developing ideas of the kind scientists can use". The value of the Origin is shown to lie in the questions asked rather than in the answers it gives. To appreciate the significance of the Darwinian system its essential function as a foundation for new research has to be realized. According to Poppor, "science advances ... not by amassing evidence in favour of hypotheses, but rather by attempts to refute them". Darwin's work, so fertile in testable hypotheses, is thus assured of survival whether or not his particular riews achieve final confirmation. For many scientists, the aim of scientific research is to be able to make accurate prediction; this was not the exclusive goal for Darwin, who wrote: "The only advantage of discovering laws is to foretell what will happen and to see bearing of scattered facts". As Ghiselin says: "A theory is valued because it provides a clue as to where to look for discoveries that have yet to be made". As for the argument that Darwin was no innovator "because his idcas have roots in carlier thought", it "is like saying that there is no difference whatever between the forelimb of a lizard and the wing of a bird" because both develop in ontogeny from a similar limb bud. This is a book to buy and to read.

SYDNEY SMITH

\section{GURUS AND EPIGROOKS}

\section{Grooks}

By Piet Hein. Pp. 53.

\section{More Grooks}

By Piet Hein. Pp. 53.

(Hodder Prperbacks: London, December 1969.) 6s cach.

THe work of the Danish writer Piet Hein may carry a particular appeal for scientists becanse sevoral of his pooms bear the impress of his days at the Niels Bohr Institute. The poems, however, are not so much verses as apophthegms, cast in rhymod form, which combine tho precision of an cpigram with the dispassion of a guru; whether for this or other reasons, Hein has chosen to call them "grooks".

Books of grooks have apparently sold 500,000 copies in Denmark, a country of 5 million people, and the English versions havo so natural a domeanour that there seems no obstacle to their gaining a proportional readership. The first thing to be said about grooks is that they aro not as simple as they sound; thcy grow on the reader to the extent that their collective effect is greater than the sum of the individual parts.

The blurb compares grooks with the Old Nordic Havamal poems (a claim the present reviewer is not qualificd to 